\title{
Guidelines for Integrating Character Education in Materials
}

\author{
Elsa Maria Marahati \\ English Education Department \\ Universitas Negeri Yogyakarta \\ Yogyakarta, Indonesia \\ Elsamaria.2017@student.uny.ac.id
}

\author{
Pangesti Wiedarti \\ English Education Department \\ Universitas Negeri Yogyakarta \\ Yogyakarta, Indonesia \\ Pangesti2018@gmail.com
}

\begin{abstract}
Character education has been considered necessary for the development of students' characters. Therefore, English language teaching should include character values in its materials. Considering the existence of English textbooks which included values contradicting with the principles of Indonesia, guidelines to develop materials were needed by material developers and English language teachers. Thus, this article aims to propose guidelines in developing morality-oriented materials based on Indonesian context. The proposed guidelines were created by reviewing the relevant literature and considering some perspectives in communicative competence and intercultural competence. In addition, the guidelines emphasized the importance of stating the correct learning objectives, selecting the appropriate teaching methods and class activities.
\end{abstract}

Keywords-Character education, EFL textbooks, morality- oriented materials.

\section{INTRODUCTION}

Character education has been receiving significant attention in Indonesia recently. This is proven by the establishment of national educational movement called PPK or Character Education Movement through Presidential Regulation number 87-year 2017. This movement was established as a response to global competition and problems that threaten the unity of Indonesia [1]. Moreover, as stated in Presidential Regulation, this movement also serves to strengthen character values in order to create cultured nation. The implementation of character education for strengthening character values is also considered to achieve the purpose of national education which is to develop students' potentials and shape their characters [2]. Therefore, considering the importance of character education to develop students' character, it is a must for formal education to support and implements character education.

At schools, character education is implemented through the teaching practices of all subjects [3], including in English as foreign language classes. In EFL classes, teachers are required to instill character values by considering the characteristics of the subject. Particular values that are recommended by the government to be prioritized in English language teaching (especially in high schools) includes friendliness, communicative, social awareness, curiosity, democratic, independent, hard work discipline, and love to read [3]. Even though the government only selected 9 out of 18 values to be prioritized, it does not mean that the other values should be abandoned. It is very recommended that the other nine-character values and even school values to be instilled during teachers' teaching practices. By inserting character values in teachers' teaching practices, it is expected that the students can develop their potentials in learning English and form their characters to become inclusive society that are prepared to face challenges of 21 st century.

One of the ways to instill character values during teaching practices is through learning materials. In English language teaching, textbooks are commonly used as learning materials in the classrooms. Considering their roles as additional knowledge source and value agents [4], English textbooks should not only focus on sets of language skills but also addressing moral values that will help the students to enhance their characters and critical minds towards themselves and their society. Therefore, it is paramount for English textbooks in classroom to manifest moral values through its texts, tasks (instructional parts) and images [4] as the goal of language education is to create not only language learners but also learners that hold knowledge of the world and serve their communities better [5].

However, despite the roles of EFL textbooks in supporting character education at schools, the notion of textbooks as value agents is still under-examined as there is not much research that discusses it, especially in Indonesian context. This is very unfortunate considering there were several cases of textbooks used in Indonesian schools that contained contents which contradicted with Indonesian values and principles, such as communism [6], pornography [7], and radicalism [8], and became a possible obstruction to young generation's development of characters. Considering the problems mentioned earlier, it is important to examine the literature and provide guidelines in developing ELT materials. Thus, this article aims to propose guidelines in developing morality-oriented materials based on Indonesian context by considering some perspectives in communicative competence and intercultural competence. 


\section{LITERATURE REVIEW}

\section{A. Character Education}

Character education is not a new phenomenon. The idea of educating for character and moral development at school has attracted attentions from several influential experts in psychology field, such as Rousseau, Dewey, Piaget, Brown, Berkowitz, Lickona and Lovat. Even though character education is not new phenomenon, there has been much debate related to its nomenclature and terminology [9]. In order to get clear idea about character education, we should define what is meant by "character" from character education perspective.

Character is defined as a complicated set of psychological characteristics which encourages someone to be a moral agent who wants to and does the right deed [10]. Such characteristics include empathy, compassion, conscience, moral reasoning, moral values, moral identity, perspective- taking, moral indignation, moral sensitivity, etc. In addition, character encompasses attitudes, behaviors, motivations and skills [11]. Having a character is more than just avoiding bad behaviors. It should be understood as the realization of one's positive development as a person, intellectually, socially, emotionally, and ethically.

Based on those definitions of character, I conclude that a character is our psychological characteristics that determine how we behave. Someone is said to have a character when she or he does right deeds to himself/herself and other people without being forced to. This means that he/she is willing to do the right deeds because he/she believes that it is the correct thing to do.

Character education therefore can be defined as the effort to develop students' characters through the implementation of school curriculum and all aspects of school life [11,4]. Such attempt is very beneficial considering the purposes of character education are to create good people, good schools and a good society [12]. However, those purposes will not be achieved without values and virtues. In fact, it is impossible to prevent societal problems and create good society, if each human being does not have values and virtues in their mind, heart and soul. Thus, character education serves to introduce and instill character values that are relevant to society. Character education gives students chances to discuss the moral values and witness how the values are practiced at their school. Eventually, a successful character education will create good people that understand and act upon the values. People who understand, care about and act upon ethical values are needed to make for a productive, fair and democratic community [11].

\section{B. The Importance of Character Education for Indonesia}

Indonesia is a developing country which ranks the fourth largest population in the world. It is home for more than two hundred million people. With large number of people, it is not surprising that each Indonesian has different physical characteristics, religions, beliefs, values, cultures and local languages. In order to create peaceful society, these differences should be accepted and appreciated by all Indonesians. Accepting and respecting the differences are reflected in the motto of Indonesia called Bhineka Tunggal Ika which means "unity in diversity." This motto is a powerful reminder for every Indonesian that they live in and fight for the same country no matter what religions they have or what local languages they speak. However, the diversity is not always appreciated by Indonesians. There were several cases where diversity caused conflicts and misunderstanding that lead to violence and even death. The example of these cases was ethnic conflict in Nduga Papua in 2017 [13]. Thirty-eight people were injured, and a person died during the conflict. In addition, the other survivors were evacuated to other cities to avoid the war. Besides ethnic conflict, Indonesia is also prone to religious conflicts. One of the examples of religious conflicts was arson attacks on monasteries in Tanjung Balai which have caused extensive damage to either the monasteries' property or vehicles around the area [14]. These attacks were done by Muslims after a Buddhist had been accused of insulting Islam. These cases were only small examples of cases that involves religions and ethnicity. There are more cases happens in the society, such as violent eviction of certain religious groups, mass persecution, radicalism, etc.

Besides ethnic and religion conflicts, there are other cases that do not lead to violence and deaths but social discrimination. In Indonesia, it is mostly experienced by disabled people and LGBT group. The discrimination toward LGBT group and disabled people may include taking away their rights and out casting them. One of the examples of this discrimination happened in 2017 when a public university required new students to bring a form stating that they are not part of LGBT group [15]. The rejection of LGBT group in campus reflected the fear and hate towards LGBT group in education. Such discrimination also happened to a disabled student who went to a public elementary school in Klaten [16]. He was suggested by his teacher to transfer a special school because he has physical disability. These cases were very apprehensive because education institutions should become friendly environment for teaching and learning. It is impossible for teachers and lecturers to educate their students effectively if they cannot get rid of prejudice and hate to certain students. In addition, it is stated in The Law of The Republic of Indonesia Number 20 Year 2003 article 5 that citizens of Indonesia have the same right to be educated. This means that there should not be any schools and colleges that reject or expel students because of their sexual orientations and their disabilities. 
All the conflicts and discriminations that had been mentioned earlier are proofs that intolerance and disrespect to certain group of people still root firmly in our society. If this situation keeps happening for longer time, it will result in chaos and war. In order to avoid that, Indonesians should be united and work together to create peace in their homeland. However, it is impossible to be united if discrimination against certain groups still exists. Therefore, there is an urgent need to educate young generation on the importance of being inclusive in plural society by strengthening the values of inclusivity and developing their characters.

In Indonesia, the notions of instilling values and character development is not new ideas. It has been one of the foci of national education since many years ago. The Law of The Republic of Indonesia number 20-year 2003 article 3 which states that the goal of national education is to promote students' potentials in order to become creative and knowledgeable young generation, and shape their characters to be religious, responsible and democratic citizens of Indonesia. In other words, education in Indonesia does not only focus on creating intellects with great future jobs but also instilling values that will make the students become superior generation that possesses good characters. These purposes of national education match with the nature of education which is helping humans to be smart and good [17].

In shaping young generation's national characters, there are several values that are recommended by the ministry of education. The values include religiosity, honesty, tolerance, discipline, hard work, creativity, independence, democracy, curiosity, patriotism, nationalism, appreciation for achievement, friendliness, peace-loving, love to read, environmental awareness, social awareness, and responsibility [3]. When the government established PPK, these eighteen values were reflected in five main values that become the priority of PPK movement. The main values are religiosity, nationalism, independence, gotong royong (working together) and integrity. These values should become part of the curriculum and be integrated in all aspects teaching and learning process. In other words, character values are not taught in separated program or subject but should be incorporated in the teaching of all subjects at school. Therefore, the lesson plans, materials, and learning activities should be heavily laden with character values. Besides the values recommended by the ministry of education, schools are free to choose other values as long as they are not contradictory to the principles of Indonesia.

\section{Character Education on Textbooks}

As mentioned previously, character education is implemented through the teaching practices of all subjects, including in English as foreign language classes [3]. Therefore, it is compulsory for EFL teachers to instill moral and cultural values that are suitable with the characteristics of English subject and the principles of Indonesia. The instruction of moral education is natural for English for foreign language classes considering English language education discipline is adaptable to the dynamics of moral values [18]. In addition, English is an international language used by people in various academic disciplines and professional fields. It is English language teachers' job to expand students' critical point of view and attitudes towards themselves, their own people, people from other cultures, their own national values, and other nations' values [19]. Thus, students can have positive character traits when they communicate with people with different cultures, characters and beliefs.

The goal of foreign language learning related to the ability to use language to communicate with people in various situations. Therefore, the point of English language teaching is to help the students develop communicative competence. The most recent framework for developing students' communicative competence is made by Celce- Murcia in 2007 [20]. This framework indicates that in learning English, language learners are expected to master grammar accuracy, understand the meaning of words and have certain degree of familiarity with native speakers' culture. Unfortunately, this native speaker model implies that English language learners should be "linguistically schizophrenic" and forsaking their own languages to be accepted in native speakers' linguistic environment [21]. As the communicative competence framework only emphasizes on how language learners communicate effectively, it is possible that they abandon culture and values in their own society while trying to be more familiar with the target language's culture.

Considering the problem as mentioned earlier, some principles in foreign language learning that has been used for English language teaching may not be suitable with Indonesian learners who have been living in a society that holds different cultures and values. Therefore, English language teaching in Indonesia should include the knowledge of target language's culture accompanied by some learning activities that enable them to compare the native speakers' cultures to their own cultures. In addition, they can also use the opportunity to discuss sensitive moral issues in the society, such as discrimination, radicalism, mass persecution, etc. Such activities are considered very beneficial for students as they do not only learn how to communicate or produce written text in English, but also learn to be a culturally competent learners who hold desirable characters and critical minds.

\section{GUIDELINES FOR MORALITY-ORIENTED MATERIALS}

As part of the curriculum, it is compulsory that EFL textbooks used in classroom include character 
values that are suitable with the principles of Indonesia. Character values can be integrated through learning objectives, teaching methods, and class activities.

\section{A. Learning Objective of Materials}

In developing EFL materials, we should focus on the values that are deemed important for the students' future and language skills. In selecting values to be integrated in materials, material developers need to be very careful. This is because language learners may come from different ethnics and religions, thus the selected values should be the ones which are widely shared by the society. For example, honesty, patience, diligence, love, respect, etc. In addition, shared values in relation to peace such as tolerance, equity, caring, empathy, and cultural values such as gotong royong also needs to be integrated to create more inclusive society. As for language skill, we should aim for communicative competence as it is the primary goal for foreign language learning. However, teachers and material developers should not only focus on language competence, they need to consider students' intercultural competence. We can adopt or modify the learning objectives from Celce-Murcia's framework [20] and Byram's intercultural competence framework [21]. These models will complement each other as the former emphasizes on language competence and the latter emphasizes on intercultural competence. However, teachers and material developers can use any models if they complement each other and promote students' intercultural awareness.

\section{B. Teaching Methods}

In developing language materials, we should consider teaching methods that is suitable for students. In addition, the selected teaching methods should enable students to discuss local and global moral issues that happen in Indonesia or other countries. Several teaching methods which teachers should consider are content-based instruction, genrebased approach, cultural studies, literature-based instruction, humanistic language teaching [5] and text-based model [22]. These methods emphasize on reading texts and discussing values inserted on the texts, journal writing, and written or oral responses to simulations. Furthermore, the tasks included in materials should be the ones that focus on students' language skills and moral values, such as task completion comparable to real-world activities, some communication problems to solve, and task assessment in terms of learning outcomes. These task characteristics allow material developers to use morality issues in both local and global cultures as some input or core activities that encourage earners to be involved in learning activities for expected learning outcomes. By including local and global issues in learning materials, students can learn to be aware of the problems that happen in their society and in the world and think critically about the solutions.

\section{Class Activities}

The learning activities should be designed to enhance students' active participation in the classroom. The activities should enable the students to exercise their language skills and develop their characters. Class activities that can be used to develop students' characters include class discussion and question responses, outdoor investigations and writing projects, simulations and role play brainstorming and community service projects, problem-solution exercises, and any exercises supporting critical reasoning [5]. Cooperative learning enables students to fill language gaps and encourages students to argue and seek ways for problem solving, and teachers are the key agents mediating any conflicting views. Through cooperative learning, students can learn the values of gotong royong, tolerance, friendliness and respect as they try to work with their classmates. However, when using cooperative learning as one of the class activities, it is necessary to consider the techniques of grouping the students, especially if the classroom consists of students with different cultures, religions and proficiencies. Any techniques of grouping selected by teachers should enable the students to cooperate and help each other.

\section{CONCLUSION}

Values and language teaching are two inseparable things. The goals of education are not only about teaching knowledge and skill but also shaping students' characters in order to prepare them for their future. Therefore, language teaching is not value-free as the teachers needs to instill certain values that will help the students become intellects who hold desirable characters and critical minds. As language teaching is not values-free, how EFL materials are developed may influence the way the students think and behave. Therefore, EFL materials that are used in classroom should include character values which are suitable with the principles of Indonesia. The guideline of developing EFL materials as proposed in this paper is based on some views on intercultural competence, communicative competence, and character education. These guidelines will be beneficial for English language teachers or material developers who are interested in making materials such as textbooks in Indonesian context. Given that the guideline is flexible for each purpose of the materials developed, material developers can use any of the discussed points to suit the needs of their materials audience. However, as the guideline only covers learning objective, teaching methods and class activities, it is recommended that English language teachers and material developers provide more guidelines about learning assessment for Indonesian context. 


\section{ACKNOWLEDGEMENT}

This paper is not funded by any institutions.

\section{REFERENCES}

[1] Kemdikbud, "Modul pelatihan penguatan pendidikan karakter (Character education training module)," Jakarta: Kemdikbud, 2017, pp. 1-58.

[2] Kemendiknas, "Desain induk pendidikan karakter (Grand design of character education)," Jakarta: Kemendiknas, 2010, pp. 2-6.

[3] Puskubruk, "Pengembangan pendidikan budaya dan karakter Bangsa: pedoman sekolah (Development of nations' culture and characters: guidelines for school," Jakarta: Kementerian Pendidikan Nasional Badan Penelitian dan Pengembangan Pusat Kurikulum, 2010, pp. $1-30$.

[4] H. P. Widodo, "A critical micro-semiotic analysis of values depicted in the Indonesian Ministry of National Education-endorsed secondary school English textbook," In Situating moral and cultural values in ELT materials: the Southeast Asian context, H.P Widodo, M. R. Perfecto, L.V. Canh, and A. Buripakdi, Cham: Springer, 2018, pp. $131-151$.

[5] S. Thongrin, "Integrating moral education into language education in Asia: guidelines for materials," In Situating moral and cultural values in ELT materials: The Southeast Asian context, H.P Widodo, M.R. Perfecto, L.V. Canh, and A. Buripakdi, Cham: Springer, 2018, pp.153 - 173.

[6] S. Wiryono, 80 Buku pegangan UN SMA memuat logo palu arit ditarik. 2017. Available from: https://www.merdeka.com/peristiwa/80-buku-peganganun-sma- memuat-logo-palu-arit-ditarik.html.

[7] Y. Iskandar, Buku lks smp Mojokerto bergambar Miyabi. 2012.Available from: http://www.tribunnews.com/regional/2012/09/20/bukulks-smp- mojokerto-bergambar-miyabi.

[8] Rompis, Buku pelajaran mengandung radikalisme. 2018. Available from: http://manado.tribunnews.com/2018/06/11/buku-pelajaranmengandung-radikalisme.

[9] M. W. Berkowitz "The complete moral person: anatomy and formation" In Moral issues in psychology: personalist contributions to selected problems, J.M. Dubois, Eds. Lanham: University Press of America, 1997, pp. 11-41.

[10] M. W. Berkowitz and M. C. Bier "Character education parents as partners," In Character education and gifted children. High Ability Studies, M.W. Berkowitz, and M.C. Bier, 2009, pp. 132-142.

[11] Battistich, Character education, prevention, and positive Youth Development. 2005. Available from: https://www.character.org/wpcontent/uploads/2011/12/Wh ite_Paper_Battistich.pd.

[12] T. Lickona, "Character education: seven crucial issues," Action in Teacher Education, 1999, pp. 77-84.

[13] C. A. Suripatty, Perang suku di Nduga Papua 1 tewas 38 lainnya terluka. 2017. Available from https://news.okezone.com/view/2017/07/02/1/39340/peran g-suku-di- nduga-papua-1-tewas-38-lainnya-terluka.

[14] Argus, Ini kronologi pembakaran vihara dan 4 klenteng di Tanjung Balai. 2018. Available from: http://medan.tribunnews.com/ini- kronologi-pembakaranvihara-dan-4-klenteng-di-tanjungbalai.

[15] E. A. Faruqi, Rektor Unand ogah cabut syarat mahasiswa baru bebas lgbt. 2017. Available from: https://nasional.tempo.co/read/871563/rektor-unand-ogahcabut-syarat-mahasiswa-baru-bebas-lgbt-ada-apa.

[16] M. Wismabrata, Kaki cacat, seorang anak ditolak sekolah. 2012. Vailable from: https://regional.kompas.com/read/2012/09/25/16211095/K aki.Cacat. Seorang.Anak.Ditolak.Sekolah.
[17] Sudrajat, "Mengapa pendidikan karakter? (Why character education?)" Jurnal Pendidikan Karakter, 2011, pp. 47-58

[18] K. Shaaban, "A proposed framework for incorporating moral education into the ESL/EFL classroom," Language, Culture and Curriculum, 2005, pp. 201-217.

[19] H. P. Widodo, M. R. Perfecto, L. V. Canh, and A. Buripakdi, "Incorporating cultural and moral values into ELT materials in the context of Southeast Asia," In Situating moral and cultural values in ELT materials: the Southeast Asian context, H.P Widodo, M. R. Perfecto, L.V. Canh, and A. Buripakdi, Cham: Springer, 2018, pp. $1-14$

[20] M. Celce-Murcia, "Rethinking the role of communicative competence in language teaching," In Intercultural language use and language learning, E. A Soler and M. P. Safont Jordà, Eds. Dordrecht: Springer,2007, pp. 41-57.

[21] M. Byram, "Teaching and assessing intercultural communicative competence," Clevedon: Multilingual Matters, 1997.

[22] M. Lipman, "Ethical reasoning and the craft of moral practice, "Journal of Moral Education, 1987, pp. 139-147. 